\title{
Aplastic Crisis as Primary Manifestation of Systemic Lupus Erythematosus
}

\author{
Philipp Baumann ${ }^{a} \quad$ Andreas Völkl ${ }^{a} \quad$ Michael Bäuerle $^{b} \quad$ Ralf Schmidmaier $^{a} \quad$ Fuat S. Oduncu $^{a}$

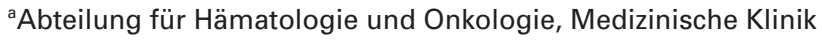 \\ ${ }^{\mathrm{b}}$ Abteilung für Rheumatologie, Medizinische Poliklinik, Campus Innenstadt der LMU München
}

Keywords

Systemic lupus erythematosus - Aplasia - Bone marrow

\section{Summary}

Aplastic crisis is an unusual feature of systemic lupus erythematosus (SLE). We report the case of a 54-year-old woman presenting with both (extravascular) Coombs-positive hemolytic anemia and laboratory findings of bone marrow hyporegeneration with concomitant severe neutropenia. A bone marrow biopsy confirmed aplastic crisis. Diagnostic work-up revealed soaring titers of autoantibodies (anti-nuclear, anti-double-stranded DNA, anti-cardiolipin$\lg \mathrm{M}$, and anti- $\beta 2$-glykoprotein-lgM antibodies), indicating a connective tissue disease as the most plausible reason for bone marrow insufficiency. As the criteria for SLE were fulfilled, we initiated an immunosuppressive therapy by steroids, which led to a rapid complete hematologic and clinical remission in our patient. In this case, we could report on one of the rare cases of SLE-induced aplastic crisis showing that this condition can be entirely reversed by immunosuppressive treatment and that SLE-induced aplastic crisis yields a good prognosis. In conclusion, in a case of aplastic crisis, physicians should be aware that SLE can be a rare cause that is accessible to specific treatment.

\section{Introduction}

Anemia, leukopenia and thrombozytopenia due to peripheral destruction are common features in systemic lupus erythematodes (SLE). Aplastic crisis, however, is rare. In this case report we describe a patient with severe hemolytic anemia and neutropenia as the first manifestation of SLE. Treatment with corticosteroids resulted in a complete clinical and hematological remission.

\author{
Schlüsselwörter \\ Systemischer Lupus Erythematosus · Aplasie . \\ Knochenmark
}

\section{Zusammenfassung}

Eine aplastische Krise stellt eine seltene Komplikation des Systemischen Lupus Erythematosus (SLE) dar. Wir beschreiben den Fall einer 54-jährigen Frau, welche sich mit extravaskulärer, Coombs-positiver, hämolytischer, hyporegeneratorischer Anämie und begleitender schwerer Neutropenie vorgestellt hat. Eine aplastische Krise wurde zytomorphologisch bestätigt. Die weitere Diagnostik ergab hohe Titer für anti-nukleäre Antikörper. Bei Nachweisbarkeit von Autoantikörpern gegen Doppelstrang-DNS, Cardiolipin und 2-Glykoprotein bestand der Verdacht auf eine Bindegewebserkrankung. Die ACR Kriterien für SLE waren erfüllt. Die Einleitung der Kortikosteroidtherapie führte zu einer raschen Rekonstitution der Hämatopoese und klinischen Remission. Zusammenfassend beschreiben wir eine Patientin mit SLE-induzierter aplastischer Krise, bei welcher mit alleiniger Steroidtherapie eine komplette Remission erzielt werden konnte. Ärzte sollten bei Patienten mit aplastischer Krise auch an seltene Ursachen wie SLE denken.

\section{Case Report}

\section{Medical History}

A 54-year-old woman was admitted to our hospital due to fever that had persisted for 3 weeks. Furthermore, she complained of loss of appetite, lassitude, night sweats, and very subtle and fluctuating joint pain. The patient remembered polytope arthralgias without swelling at the elbows, knees, wrists and fingers, which had occurred several months before admission. The patient reported no further complaints; no skin lesions or other clinical signs of lupus were detectable in the physical examination. Extensive anamnesis revealed no photosensitivity, oral ulcers, rash, oral and/or genital ulcers, Raynaud's or signs of arthritis. Beyond, there was no history of thromboembolic events. Of concern, the medical history revealed an episode of steroid refractory autoimmune hemolytic anemia

\section{KARGER \\ Fax +497614520714 \\ Information@Karger.de}

www.karger.com (c) 2011 S. Karger GmbH, Freiburg

0378-584X/11/0348-0452\$38.00/0

Accessible online at:

www.karger.com/onk 
in 1994, resolved after splenectomy. Thereafter, the patient remained free of symptoms. The immediate previous history showed no signs of infection like cough, dysuria or diarrhea. Amoxicillin had been prescribed by the primary practitioner 3 weeks before admission since she had then suffered from cough and fever.

\section{Physical Examination}

At admission, the patient had fever $\left(39^{\circ} \mathrm{C}\right)$, an increased respiratory rate of 25/min and palpable cervical, axillary and inguinal lymphadenopathy. Blood pressure was normal at $110 / 75 \mathrm{mmHg}$, oxygen saturation at $95 \%$ without insufflation of oxygen.

\section{Laboratory Findings}

A hemogram revealed a white blood cell (WBC) count of 800 cells/ $\mu$ with only $14 \%$ neutrophils, a hemoglobin concentration of $2.3 \mathrm{~g} / \mathrm{dl}$ (normal range $12-16 \mathrm{~g} / \mathrm{dl}$ ), a hematocrit of $7 \%(37-46 \%)$ and reticulocytes of $8 \%$ (4-15\%; reticulocyte production index 0.1 (normal value 1 ); absolute reticulocyte count $\left.8 \times 10^{3} / \mu \mathrm{l}\right)$. The platelets at $295 \mathrm{G} / \mathrm{L}(150-400 \mathrm{G} / \mathrm{L})$, mean corpuscular hemoglobin $(\mathrm{MCH})$ and mean corpuscular volume (MCV) were within normal range. Ferritin was elevated $(7155 \mu \mathrm{g} / \mathrm{l}$, normal range $30-200 \mu \mathrm{g} / \mathrm{l})$, transferrin at $1.8 \mathrm{~g} / \mathrm{L}(2-4 \mathrm{~g} / \mathrm{l})$, C-reactive protein at $1.5 \mathrm{mg} /$ $\mathrm{ml}(<0.5 \mathrm{mg} / \mathrm{ml})$, albumine at $3.2 \mathrm{~g} / \mathrm{dl}(3.5-5.5 \mathrm{~g} / \mathrm{dl})$, lactate dehydrogenase $(\mathrm{LDH})$ at $506 \mathrm{U} / 1$ (135-214 U/L), haptoglobin < $10 \mathrm{mg} / \mathrm{dl}(20-204 \mathrm{mg} / \mathrm{dl})$. All other routinely assigned parameters were within normal range.

\section{Work-Up}

High LDH and undetectable haptoglobin in association with anti-erythrocyte autoantibodies suggested hemolysis in our patient (direct Coombs' test titer: $1: 100<\mathrm{x}<1: 300 ; \operatorname{IgG} 3>1: 100, \operatorname{IgG} 1<1: 100)$. The very low reticulocyte production index and the neutropenia additionally revealed bone marrow insufficiency. This suspicion was proven by a bone marrow aspiration and biopsy as shown in figure 1. Infiltration of the bone marrow by lymphoma or leukemia could be ruled out by immune flow cytometry and by missing cytomorphologic changes in the marrow.

Furthermore, histology and cytomorphology showed hypocellular bone marrow with severe hypoplasia of granulopoiesis and erythropoiesis, matching the diagnosis of aplastic crisis. Thrombopoiesis was not altered in the bone marrow nor were pathologic platelet counts found in the peripheral blood.

The medical history was negative for therapy with cytotoxic drugs or irradiation and negative for medication or toxic substances that are known to induce an aplastic syndrome. Paroxysmal nocturne hemoglobinuria, leukemia, lymphoma and myeloproliferative neoplasias were excluded by flow cytometry and cytomorphology. Accessory spleen after splenectomy was excluded by abdominal ultrasound. Serological tests for Epstein-Barr virus (EBV), cytomegalovirus (CMV), viral hepatitis and parvo B19 virus were negative.

Initial clinical examination revealed cervical, axillary and inguinal lymphadenopathy, which was proved by a computed tomography (CT) scan. Additionally, little bilateral pleural effusions were detected. An extirpation and histological analysis of an axillary lymph node showed only reactive changes, without being suspicious of specific infections or malignant diseases.

Serological work-up for autoantibodies was performed. Titers for antinuclear antibodies were dramatically elevated (1:30,720), anti-doublestranded DNA monoclonal antibodies were slightly positive (10 U/1, normal range $<9 \mathrm{U} / 1)$. Anti-cardiolipin-IgM antibodies and anti- $\beta 2$-glykoprotein-IgM antibodies were notably elevated. Antibodies against sm, SS-A, SS-B, Scl-70 and Jo-1 were negative. Mild to moderate C3-hypocomplementemia was seen $(65.5 \mathrm{mg} / \mathrm{dl}$, normal range $80-180 \mathrm{mg} / \mathrm{dl})$.

Finally, diagnosis of SLE was confirmed according to the American College of Rheumatology (ACR) criteria [1] with the following positive findings: serositis (pleural effusions), hematologic findings (hemolysis, neutropenia), detection of anti-double-stranded DNA antibodies and anti-nuclear antibodies.

\section{Treatment}

Due to suspected autoimmune hemolytic anemia, the patient was treated with $100 \mathrm{mg}$ prednisolone per day from the first day of admission. On day 7 after admission, the patient developed reticulocytosis (100/1000 erythrocytes) and the peripheral blood completely normalized within weeks. 2 weeks after initiation of steroid treatment, reticulocytosis had resolved and $\mathrm{LDH}$ had declined to normal levels. Haptoglobin was decreased at admission and was found to be normal 1 month after initiation of steroid treatment.

Corticosteroids were tapered down to $10 \mathrm{mg}$ daily, and an immunosuppressive therapy with azathioprine was initiated. With the time of treatment, all signs of disease resolved. 6 months after the diagnosis of SLE, the patient has a normal blood count.

\section{Discussion}

Hematological manifestations are not rare in SLE and occur in up to $85 \%$ of patients during the course of the disease $[2,3]$. Peripheral destruction of cells is responsible for most changes. Aplastic anemia is a very rare finding in SLE, and only a few case reports are found in the literature [4-6]. Here, we show a case with SLE presenting as aplastic crisis with neutropenia and anemia. Therapy with steroids led to a complete recovery of the peripheral blood count and laboratory changes of hemolysis.

Hematological abnormalities in SLE are common. Anemia frequently occurs in SLE due to chronic inflammation, renal disease, or immunosuppressive therapy. Autoimmune hemolysis, particularly, occurs in about $10 \%$ of all cases with SLE [7]. Pure red cell aplasia, in which autoantibodies are directed against erythropoietin, is rather rare. Thrombocytopenia, also
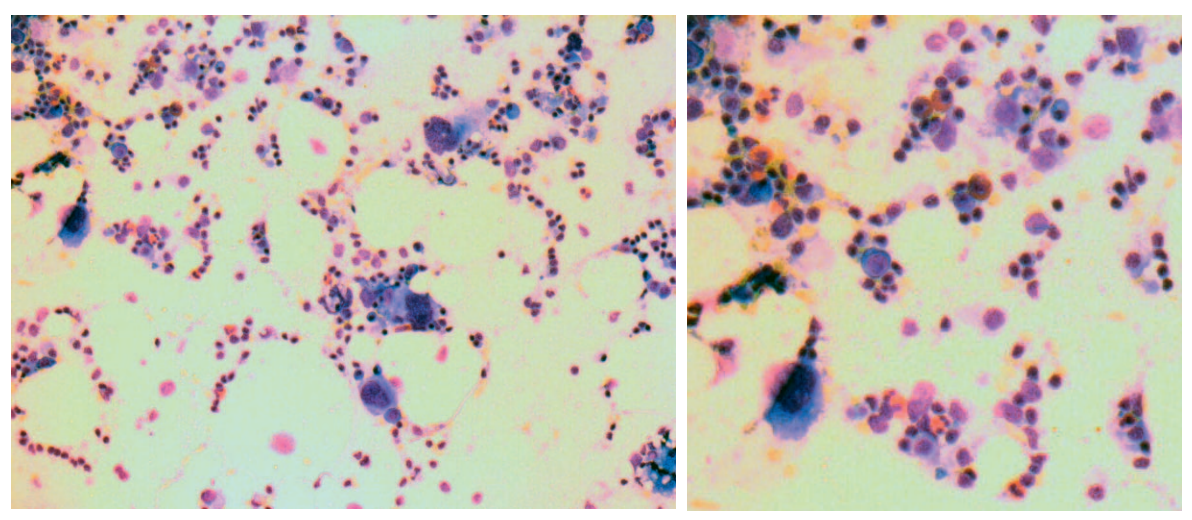

Fig. 1. Morphologic changes in bone marrow cytology. 
a common complication of SLE, may be caused by autoimmune thrombocytopenia (ITP) or immunosuppressive therapy. ITP may be the initial presentation of disease in about $15 \%$ of all patients with SLE [8]. In our patient, thrombocytopenia was absent. Leukopenia is also very common in patients with SLE. It is mostly due to immunosuppressive drugs or mediated by autoantibodies directed against neutrophils and/or lymphocytes.

Aplastic anemia is a severe disorder of the bone marrow with an incidence of 4/1,000,000 per year. The disease is idiopathic in $80 \%$ of all cases. Drugs might be responsible; other causes could be viral infections (EBV, CMV, hepatitis and parvo B19 virus), chemicals and a few others. The responsiveness of aplastic anemia to immunosuppressive agents is the best evidence for the underlying immune mechanism of this disease: Autoreactive T cells lead to the destruction of hematopoietic stem cells and can be inhibited by immunosuppressive agents, especially antithymocyte globulins (ATG) [9, 10]. Besides the pivotal role of autoreactive T cells, autoantibodies against various proteins like kinectin, moesin and diazepam-binding inhibitor-related protein have been described and their at least subsidiary role in the pathophysiology of aplastic anemia has been suggested [11-15].

In SLE, aplastic anemia is a rare finding and only a few cases have been reported in the literature [16]. Like idiopathic aplastic anemia, SLE-induced aplastic anemia seems to be immune mediated. Both cellular-mediated and antibodymediated inhibition of hematopoietic cell growth have been reported so far. Several authors described a cryptic serum inhibitor, for example in the acute phase of aplastic anemia, that inhibits colony-forming units in vitro through complement-dependent IgG [17]. Furthermore, Wolach et al. [18] described a case of anti-Ro-positive SLE, and Bailey et al. [6] described a case of lupus with evidence of anti-neutrophil antibodies. Others report cell-dependent mechanisms for aplastic anemia in SLE [5, 18]. However, the exact mechanisms of SLE-induced aplastic anemia to date are not yet fully understood and might be multifaceted. Yet, in contrast to idiopathic aplastic anemia [19], prognosis of SLE-induced aplastic anemia is good, with no documented recurrence or transfusion dependence.

Cornerstones of supportive care in patients with SLE-induced aplastic anemia are red cell and platelet transfusions and antibiotics. Considering therapy of SLE-induced aplastic anemia, some patients respond to oral steroids alone [5, 18], while others need parenteral steroid or plasmapheresis or even further immunosuppression using cyclophosphamide [16]. Other treatment options include cycloporine A [20]. Steroid non-responders might benefit from azathioprine or methotrexate.

\section{Disclosure Statement}

The authors declare that they have nothing to disclose.

\section{References}

1 Tan EM, Cohen AS, Fries JF, Masi AT, McShane DJ, Rothfield NF, Schaller JG, Talal N, Winchester RJ: The 1982 revised criteria for the classification of systemic lupus erythematosus. Arthritis Rheum 1982;25:1271-1277.

2 Pavithran K, Raji NL, Thomas M: Aplastic anemia complicating systemic lupus erythematosus report of a case and review of the literature. Rheumatol Int 2002;22:253-255.

3 Singh NP, Prakash A, Garg D, Makhija A Pathania A, Prakash N, Kubba S, Agarwal SK: Aplastic anemia complicating systemic lupus erythematosus: Successful management with cyclosporine. Rheumatol Int 2004;24:40-42.

4 Marques JA, Rhim H, Distenfeld A: Inhibition of hematopoiesis by a plasma factor in a case of aplastic anemia associated with systemic lupus erythematosus. P R Health Sci J 1995;14:293-296.

5 Chute JP, Hoffmeister K, Cotelingam J, Davis TA, Frame JN, Jamieson T: Aplastic anemia as the sole presentation of systemic lupus erythematosus. Am J Hematol 1996;51:237-239.

6 Bailey FA, Lilly M, Bertoli LF, Ball GV: An antibody that inhibits in vitro bone marrow proliferation in a patient with systemic lupus erythematosus and aplastic anemia. Arthritis Rheum 1989:32:901905 .
7 Alger M, Alarcon-Segovia D, Rivero SJ: Hemolytic anemia and thrombocytopenic purpura: Two related subsets of systemic lupus erythematosus. J Rheumatol 1977;4:351-357.

8 Mestanza-Peralta M, Ariza-Ariza R, Cardiel MH, Alcocer-Varela J: Thrombocytopenic purpura as initial manifestation of systemic lupus erythematosus. J Rheumatol 1997:24:867-870.

9 Young NS: Pathophysiologic mechanisms in acquired aplastic anemia. Hematol Am Soc Hematol Educ Program 2006:72-77.

10 Young NS, Scheinberg P, Calado RT: Aplastic anemia. Curr Opin Hematol 2008;15:162-168.

11 Hirano N, Butler MO, Von Bergwelt-Baildon MS, Maecker B, Schultze JL, O'Connor KC, Schur PH, Kojima S, Guinan EC, Nadler LM: Autoantibodies frequently detected in patients with aplastic anemia. Blood 2003;102:4567-4575.

12 Hirano N, Butler MO, Guinan EC, Nadler LM, Kojima S: Presence of anti-kinectin and anti-PMS1 antibodies in Japanese aplastic anaemia patients. Br J Haematol 2005;128:221-223.

13 Espinoza JL, Takamatsu H, Lu X, Qi Z, Nakao S: Anti-moesin antibodies derived from patients with aplastic anemia stimulate monocytic cells to secrete TNF-alpha through an ERK1/2-dependent pathway. Int Immunol 2009;21:913-923.

14 Takamatsu H, Espinoza JL, Lu X, Qi Z, Okawa K, Nakao S: Anti-moesin antibodies in the serum of patients with aplastic anemia stimulate peripheral blood mononuclear cells to secrete TNF-alpha and IFN-gamma. J Immunol 2009;182:703-710.

15 Feng X, Chuhjo T, Sugimori C, Kotani T, Lu X, Takami A, Takamatsu H, Yamazaki H, Nakao S: Diazepam-binding inhibitor-related protein 1: A candidate autoantigen in acquired aplastic anemia patients harboring a minor population of paroxysmal nocturnal hemoglobinuria-type cells. Blood 2004;104:2425-2431.

16 Tagoe C, Shah A, Yee H, Belmont HM: Aplastic anemia in systemic lupus erythematosus: A distinct presentation of acquired aplastic anemia? J Clin Rheumatol 2001;7:377-383.

17 Brooks BJ Jr, Broxmeyer HE, Bryan CF, Leech SH: Serum inhibitor in systemic lupus erythematosus associated with aplastic anemia. Arch Intern Med 1984;144:1474-1477.

18 Wolach B, Choc L, Pomeranz A, Ben Ari Y, Douer D, Metzker A: Aplastic anemia in neonatal lupus erythematosus. Am J Dis Child 1993;147: 941-944.

19 Torok-Storb B, Doney K, Sale G, Thomas ED, Storb R: Subsets of patients with aplastic anemia identified by flow microfluorometry. N Engl J Med 1985;312:1015-1022.

20 Hinterberger-Fischer M, Hocker P, Lechner K, Seewann H, Hinterberger W: Oral cyclosporin-A is effective treatment for untreated and also for previously immunosuppressed patients with severe bone marrow failure. Eur J Haematol 1989;43:136-142. 